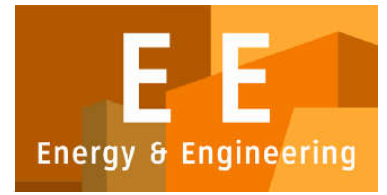

PAPER - OPEN ACCESS

\title{
Optimisasi Stasiun Kerja melalui Minimisasi Bottleneck dengan Pendekatan Theory Of Constraint
}

\author{
Author \\ : Dini Wahyuni, dkk \\ DOI \\ : 10.32734/ee.v2i3.755 \\ Electronic ISSN \\ : 2654-704X \\ Print ISSN \\ : 2654-7031
}

Volume 2 Issue 3 - 2019 TALENTA Conference Series: Energy \& Engineering (EE)

\section{(ㅇ) $(0 \Theta$}

This work is licensed under a Creative Commons Attribution-NoDerivatives 4.0 International License.

Published under licence by TALENTA Publisher, Universitas Sumatera Utara

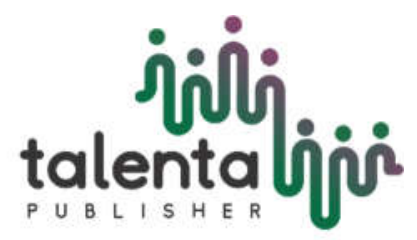




\title{
jibli

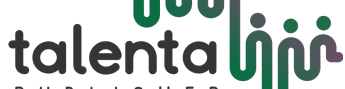 \\ EE Conference Series 02 (2019)

\section{Optimisasi Stasiun Kerja melalui Minimisasi Bottleneck dengan Pendekatan Theory of Constraint}

\author{
Dini Wahyuni ${ }^{1}$, Irwan Budiman ${ }^{2}$, Esa Pasaribu ${ }^{3}$, Jeffrey Panama ${ }^{4}$ \\ ${ }^{1}$ Departemen Teknik Industri, Fakultas Teknik, Universitas Sumatera Utara \\ ${ }^{2}$ Program Studi Teknik Industri, Fakultas Teknologi dan Ilmu Komputer, Universitas Prima Indonesia \\ ${ }^{1}$ diniwahyuni2015@gmail.com, ${ }^{2}$ irwanb01@gmail.com, ${ }^{4}$ jeffreypanama.usu@ gmail.com
}

\begin{abstract}
Abstrak
Penelitian ini dilakukan pada salah satu perusahaan penghasil RSS (Ribbed Smoke Sheet) dan CR (Crumb Rubber) setengah jadi. Proses produksi dilakukan berdasarkan make to order. Hasil pengamatan di lantai produksi menunjukkan banyaknya penumpukan di stasiun pengasapan dan sortasi. Penumpukan tersebut disebabkan karena adanya perbedaan kapasitas antara stasiun pengasapan dan sortasi dengan stasiun sebelumnya, sehingga menjadi masalah yang harus diselesaikan. Pada penelitian ini digunakan metode Theory Of Constraint (TOC) untuk mengoptimalkan stasiun kerja bottleneck. Hasil perhitungan kapasitas dengan metode RCCP diperoleh kapasitas yang dibutuhkan dan kemudian membandingkannya dengan kapasitas yang tersedia sehingga diketahui stasiun kerja yang mengalami bottleneck adalah stasiun pengasapan dan sortasi. Pengolahan data dengan metode TOC dilakukan dengan beberapa langkah yaitu identifikasi kendala yang dilakukan pada hasil perhitungan RCCP. Kemudian melakukan eksploitasi kendala untuk mencari solusi-solusi yang mungkin dilakukan. Setelah itu melakukan subordinasi sumber daya yaitu dengan mencari alternatif penyelesaian yang layak ditempuh. Hasil penelitian merekomendasikan stasiun sortasi melakukan penambahan jam kerja selama 2 jam pada bulan Januari, Juli, Agustus, September, Oktober, November, Desember. Sedangkan untuk stasiun pengasapan dilakukan perluasan area kamar pengasapan.
\end{abstract}

Kata Kunci: Bottleneck, Theory of Constraint (TOC), RCCP

\begin{abstract}
This research was conducted at one of the companies producing RSS (Ribbed Smoke Sheet) and CR (Crumb Rubber) semifinished. The production process is based on make to order. The observations on the production floor showed the amount of buildup at the smoking and sorting stations. The buildup is caused by differences in capacity between the smoking and sorting stations and the previous stations, so it becomes a problem that must be resolved. In this research, the Theory Of Constraint (TOC) method is used to optimize the work station bottleneck. The results of the capacity calculation using the RCCP method obtained the required capacity and then compare it with the available capacity so that it is known that the work stations experiencing bottlenecks are the smoking and sorting stations. Data processing using the TOC method was carried out with several steps, namely the identification of obstacles that were made on the results of the RCCP calculation. Then exploit the constraints to find possible solutions. After that, subordinating the resources by finding alternative solutions that are feasible. The results of the study recommend that the sorting station increase work hours for 2 hours in January, July, August, September, October, November, December. As for the smoking station, the area is expanded to the smoking room.
\end{abstract}

Keywords: Bottleneck, Theory of Constraint (TOC), RCCP

(C) 2019 The Authors. Published by TALENTA Publisher Universitas Sumatera Utara

Selection and peer-review under responsibility of The 3nd National Conference on Industrial Engineering (NCIE)

2019

p-ISSN: 2654-7031, e-ISSN: 2654-704X, DOI: 10.32734/ee.v2i3.755 


\section{Pendahuluan}

Perencanaan produksi sangat menentukan kemampuan perusahaan dalam penyediaan produk. Jika perencanaan produksi tidak dapat diatur dengan baik, maka dapat menyebabkan terjadinya penumpukan atau bottleneck. Bottleneck terjadi apabila stasiun kerja memiliki kapasitas lebih kecil dari kebutuhan produksi. Stasiun kerja bottleneck akan mengakibatkan terjadinya keterlambatan jika ada peningkatan permintaan yang melebihi kapasitas [1]. Beberapa cara yang biasa dilakukan untuk mengatasi stasiun bottleneck adalah penambahan mesin, peralatan, atau karyawan, maupun perbaikan metode kerja. Akan tetapi cara-cara tersebut membutuhkan modal yang besar dan waktu yang lama sehingga terkadang tidak mungkin dilakukan [2]. Untuk itu diperlukan suatu pendekatan pemecahan masalah, yaitu dengan mengoptimalkan sumber-sumber daya yang ada di pabrik serta mengelola kendala-kendala yang ada di perusahaan. Metode yang dapat digunakan untuk menyelesaikan masalah penumpukan atau bottleneck adalah 5 langkah Theory of Constraints (TOC). Theory of Constraints TOC merupakan pendekatan berkelanjutan yang berfokus pada identifikasi dan penyelesaian kendala yang membatasi perusahaan yang terdapat di dalam ataupun di luar perusahaan (kendala internal atau eksternal). Kendala internal misalnya dapat berupa perbedaan kapasitas produksi dan kapasitas waktu mesin, sedangkan kendala eksternal dapat berupa permintaan pasar. Pada penelitian ini dilakukan analisis stasiun kerja untuk mengoptimalkan sumber daya dengan pendekatan Theory of Constraints (TOC) [3].

Penelitian sebelumnya mampu mengaplikasikan TOC untuk mengurangi bottleneck yang terjadi pada stasiun kerja obras, obras lipat, hand-tag, dan packing dengan memperhatikan waktu proses dan kapasitas produksi dari stasiun kerja [4]. Penerapan TOC dalam penelitian tersebut dapat mengurangi bottleneck dengan melakukan assessment pada stasiun kerja manual corak, komputer, dan manual polos, serta menambah kapasitas pada stasiun kerja obras lipat, pairing, hand-tag, dan packing. Dengan demikian, perusahaan bisa mengurangi bottleneck tersebut dan meningkatkan throughput perusahaan [5].

Meningkatnya permintaan produk secara mendadak merupakan alasan utama dalam menggunakan konsep TOC, yaitu pengaturan kembali jumlah permintaan produk, jumlah hari kerja, waktu siklus produksi per stasiun kerja dan waktu tersedia, dan dari penerapan TOC tersebut perusahaan mendapatkan hasil yang maksimal [6]. Penelitian lain menerapkan TOC dalam penyusunan kembali JIP dalam memaksimalkan keuntungan dengan menggunakan goal programming. Penelitian tersebut membahas tentang adanya perbedaan kebutuhan kapasitas dengan kapasitas tersedia serta ditentukan kombinasi produk yang dapat meningkatkan keuntungan. Variable yang digunakan adalah data permintaan produk, rata-rata waktu proses, total biaya bahan baku, harga jual produk, upah tenaga kerja, batasan area pencetakan dan jumlah kapasitas stasiun kerja. Dengan menggunakan TOC, perusahaan dapat megoptimalkan aliran produksi, penggunaan sumber daya serta meningkatkan performansi produksi dan keuntungan perusahaan [7].

\section{Metodologi Penelitian}

Penelitian ini termasuk penelitian deskriptif kausal (descriptive causal research) dikarenakan penelitian ini bertujuan untuk mendeskripsikan secara akurat tentang fakta-fakta adanya hubungan sebab-akibat dengan cara mengamati akibat yang terjadi dan kemungkinan faktor (sebab) yang menimbulkan akibat tersebut [8]. Objek yang diamati adalah proses produksi RSS dan waktu siklus pada setiap stasiun kerja pada proses pembuatan RSS.

\subsection{Metode Pengumpulan Data}

Metode pengumpulan data dalam penelitian ini adalah:

1. Melakukan pengamatan terhadap kegiatan produksi pada masing-masing stasiun kerja.

2. Mencatat semua informasi yang berkaitan erat dengan penyelesaian pekerjaan.

3. Melakukan pengukuran waktu kerja dengan jam henti.

Metode pengukuran waktu kerja dengan jam henti dapat dilaksanakan dengan langkah-langkah berikut:

1. Mendefenisikan pekerjaan yang diteliti untuk diukur waktu kerjanya.

2. Membagi operasi kerja ke dalam elemen-elemen kerja.

3. Menetapkan jumlah siklus kerja yang harus diukur dan dicatat.

4. Mengukur dan mencatat waktu siklus tiap elemen kerja.

5. Melakukan wawancara atau tanya jawab dengan penanggung jawab bagian produksi mengenai hal-hal yang berhubungan dengan penelitian.

6. Mengumpulkan data sekunder yang diambil dari dokumen-dokumen perusahaan. 
7. Mengumpulkan data sekunder yang diperoleh dengan cara membaca pustaka atau literatur yang memiliki hubungan dengan objek yang diteliti.

\subsection{Metode Pengolahan Data}

Langkah-langkah pengolahan data dalam penelitian ini adalah:

1. Uji keseragaman data yang bertujuan untuk memastikan bahwa variasi waktu penyelesaian tiap operasi hasil pengamatan masih berada dalam batas-batas kewajaran. Tingkat kepercayaan yang digunakan adalah $95 \%$ dan tingkat ketelitian yang digunakan adalah 5\%. Selain itu juga dilakukan uji kecukupan data untuk menentukan jumlah pengamatan yang diperlukan sesuai tingkat ketelitian yang diisyaratkan.

2. Menghitung waktu standar yang dibutuhkan oleh pekerja untuk menyelesaikan suatu pekerjaan.

3. Rekapitulasi estimasi hasil lateks tanaman karet berdasarkan data pasokan bahan baku yang diperoleh dari RKAP (Rencana Kerja Anggaran Produksi)

4. Perhitungan kebutuhan kapasitas untuk mengetahui kapasitas yang dibutuhkan.

5. Menentukan Kecukupan Kapasitas dengan cara membandingkan kapasitas tersedia dengan kapasitas yang dibutuhkan. Apabila kapasitas tersedian lebih kecil daripada kapasitas yang dibuhkan, maka kapasitas pada stasiun kerja tersebut tidak cukup atau bottleneck sebaliknya apabila kapasitas tersedia lebih besar dari kapasitas yang dibutuhkan, maka kapasitas stasiun kerja tersebit cukup atau non bottleneck.

6. Melakukan pemecahan masalah dengan Theory of Constraints (TOC)

Pemecahan masalah dengan metode TCC dilakukan dengan beberapa langkah, yaitu:

a. Identifikasi kendala-kendala perusahaan

b. Mengeksploitasi kendala-kendala yang mengikat

c. Subordinasi Sumber Daya

d. Mengulangi Proses

Kerangka konsep penelitian ditunjukkan pada Gambar 1 di bawah ini.

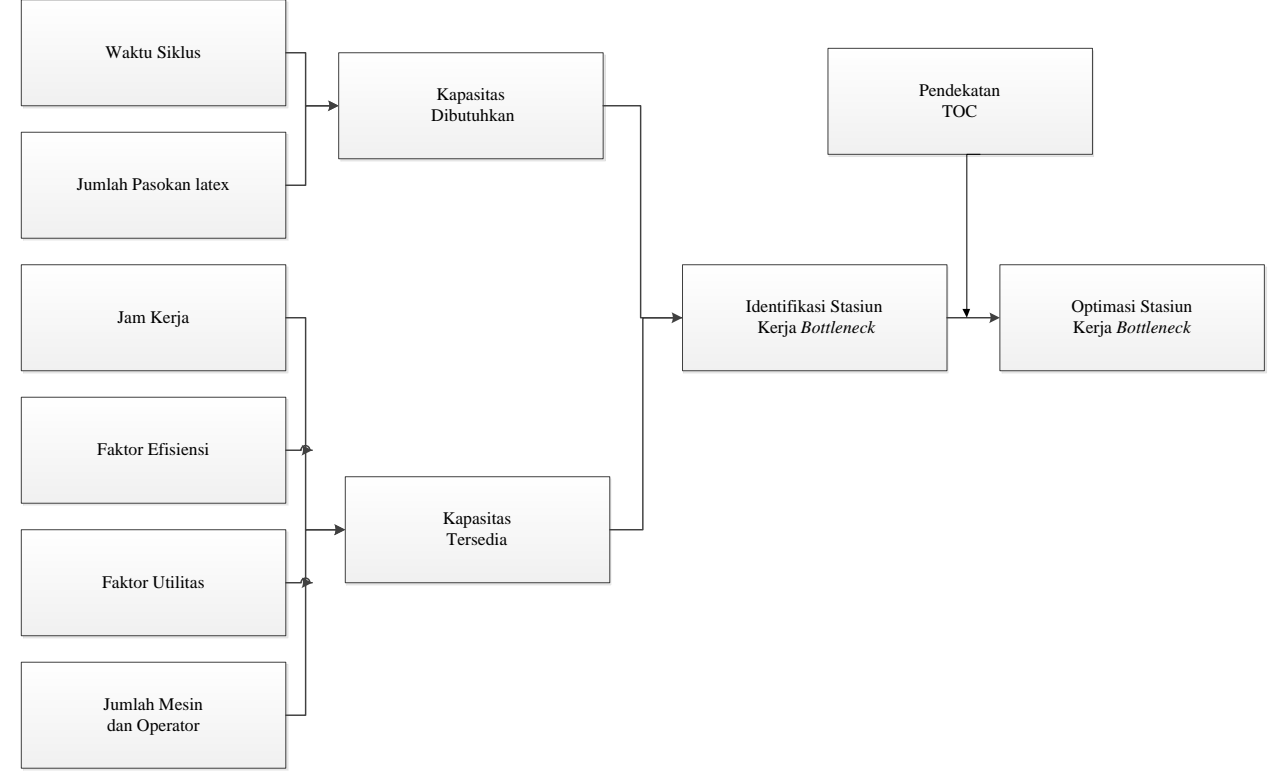

Gambar 1. Kerangka Konsep Penelitian 


\section{Hasil dan Pembahasan}

\subsection{Uji Keseragaman dan Kecukupan Data}

Data waktu siklus kerja yang diperoleh dari 10 kali pengamatan diuji keseragaman dan kecukupannya menggunakan tingkat keyakinan 95\% dan tingkat ketelitian 5\%. Waktu siklus yang diukur adalah waktu elemen kerja dari masing-masing stasiun kerja. Hasil uji keseragaman dan uji kecukupan ditunjukkan pada Tabel 1 di bawah ini.

Tabel 1. Rekapitulasi Uji Keseragaman dan Uji Kecukupan Data Waktu Siklus

\begin{tabular}{|c|c|c|c|c|c|c|c|}
\hline SK & Nama SK & EK & $\overline{\bar{X}}$ & BKA & BKB & $\mathbf{N}^{\prime}$ & Keterangan \\
\hline \multirow{4}{*}{ I } & \multirow{4}{*}{$\begin{array}{l}\text { Pengenceran } \\
\text { Lateks }\end{array}$} & 1 & 410 & 435 & 384 & 0,01 & Seragam dan Cukup \\
\hline & & 2 & 63 & 72 & 54 & 0,07 & Seragam dan Cukup \\
\hline & & 3 & 246 & 255 & 236 & 0,01 & Seragam dan Cukup \\
\hline & & 4 & 261 & 287 & 235 & 0,04 & Seragam dan Cukup \\
\hline \multirow{7}{*}{ II } & \multirow{7}{*}{$\begin{array}{l}\text { Pembekuan } \\
\text { Lateks }\end{array}$} & 1 & 15 & 21 & 8 & 0,63 & Seragam dan Cukup \\
\hline & & 2 & 76 & 83 & 69 & 0,03 & Seragam dan Cukup \\
\hline & & 3 & 12 & 14 & 9 & 0,16 & Seragam dan Cukup \\
\hline & & 4 & 354 & 375 & 333 & 0,01 & Seragam dan Cukup \\
\hline & & 5 & 7380 & 8518 & 6242 & 0,09 & Seragam dan Cukup \\
\hline & & 6 & 146 & 160 & 133 & 0,03 & Seragam dan Cukup \\
\hline & & 7 & 355 & 368 & 342 & 0,00 & Seragam dan Cukup \\
\hline \multirow{2}{*}{ III } & \multirow{2}{*}{ Penggilingan } & 1 & 116 & 124 & 108 & 0,02 & Seragam dan Cukup \\
\hline & & 2 & 525 & 532 & 519 & 0,00 & Seragam dan Cukup \\
\hline \multirow{3}{*}{ IV } & \multirow{3}{*}{ Penirisan } & 1 & 2582 & 3228 & 1935 & 0,23 & Seragam dan Cukup \\
\hline & & 2 & 64 & 73 & 55 & 0,07 & Seragam dan Cukup \\
\hline & & 3 & 14400 & 14400 & 14400 & 0,00 & Seragam dan Cukup \\
\hline \multirow{2}{*}{$\mathrm{V}$} & \multirow{2}{*}{ Pengasapan } & 1 & 53 & 66 & 40 & 0,21 & Seragam dan Cukup \\
\hline & & 2 & 86.400 & 86.400 & 86.400 & 0,00 & Seragam dan Cukup \\
\hline \multirow{2}{*}{ VI } & \multirow{2}{*}{$\begin{array}{c}\text { Sortasi/ } \\
\text { Pengepakan }\end{array}$} & 1 & 55 & 62 & 48 & 0,06 & Seragam dan Cukup \\
\hline & & 2 & 1.782 & 1.782 & 1.782 & 0,02 & Seragam dan Cukup \\
\hline \multirow{5}{*}{ VII } & \multirow{5}{*}{ Penimbangan } & 1 & 83 & 93 & 72 & 0,06 & Seragam dan Cukup \\
\hline & & 2 & 36 & 44 & 28 & 0,18 & Seragam dan Cukup \\
\hline & & 3 & 115 & 117 & 113 & 0,00 & Seragam dan Cukup \\
\hline & & 4 & 10 & 12 & 7 & 0,24 & Seragam dan Cukup \\
\hline & & 5 & 62 & 67 & 57 & 0,03 & Seragam dan Cukup \\
\hline
\end{tabular}

\subsection{Penetapan Waktu Standar}

Waktu standar adalah waktu yang dibutuhkan secara wajar oleh seorang pekerja normal untuk menyelesaikan pekerjaan yang dijalankan dalam sistem kerja yang terbaik. Sebelum memperoleh waktu standar, dilakukan perhitungan waktu normal. Adapun cara perhitungan waktu normal dan waktu standar stasiun kerja I sebagai berikut.

Waktu Normal (Wn) SK 1 = Waktu siklus rata-rata SK 1 x Rating factor SK 1

$\begin{aligned} & =410 \times 1=410 \text { detik } \\ \text { Waktu Standar (Ws) SK } 1 & =\text { Waktu normal }(\mathrm{Wn}) \text { SK } 1 \times \frac{100 \%}{100 \% \text {-Allowance }}\end{aligned}$ $=410 \times \frac{100 \%}{100 \%-7}=441$ detik

Untuk stasiun kerja lainnya dihitung dengan cara yang sama dan hasilnya tertera pada Tabel 2 di bawah ini. 
Tabel 2. Rekapitulasi Waktu Standar Tiap Stasiun Kerja

\begin{tabular}{|c|c|c|c|c|c|c|}
\hline SK & EK & $\begin{array}{c}\text { Waktu } \\
\text { Terpilih }\end{array}$ & $\begin{array}{l}\text { Rating } \\
\text { Factor }\end{array}$ & $\begin{array}{c}\text { Allow- } \\
\text { ance }\end{array}$ & $\begin{array}{c}\text { Waktu } \\
\text { Normal } \\
\end{array}$ & $\begin{array}{c}\text { Waktu } \\
\text { Standar }\end{array}$ \\
\hline \multirow{4}{*}{ I } & 1 & 410 & 1 & 7,0 & 410 & 441 \\
\hline & 2 & 63 & 1 & 6,0 & 63 & 67 \\
\hline & 3 & 246 & 1 & 0,0 & 246 & 246 \\
\hline & 4 & 261 & 1 & 8,5 & 261 & 285 \\
\hline \multirow{7}{*}{ II } & 1 & 15 & 1 & 8,5 & 15 & 16 \\
\hline & 2 & 76 & 1 & 12,5 & 76 & 87 \\
\hline & 3 & 12 & 1 & 8,5 & 12 & 13 \\
\hline & 4 & 354 & 1 & 16,5 & 354 & 424 \\
\hline & 5 & 7.380 & 1 & 0,0 & 7.380 & 7.380 \\
\hline & 6 & 146 & 1 & 12,0 & 146 & 166 \\
\hline & 7 & 355 & 1 & 14,0 & 355 & 413 \\
\hline \multirow{2}{*}{ III } & 1 & 116 & 1 & 0,0 & 116 & 116 \\
\hline & 2 & 525 & 1 & 0,0 & 525 & 525 \\
\hline \multirow{3}{*}{ IV } & 1 & 2.582 & 1 & 8,5 & 2.788 & 3.047 \\
\hline & 2 & 64 & 1 & 14,5 & 71 & 83 \\
\hline & 3 & 14.400 & 1 & 0,0 & 14.400 & 14.400 \\
\hline \multirow{2}{*}{$\mathrm{V}$} & 1 & 53 & 1 & 14,5 & 59 & 69 \\
\hline & 2 & 86.400 & 1 & 0,0 & 86.400 & 86.400 \\
\hline \multirow{2}{*}{ VI } & 1 & 55 & 1 & 14,5 & 61 & 71 \\
\hline & 2 & 1.782 & 1 & 14,5 & 1.960 & 2.293 \\
\hline \multirow{5}{*}{ VII } & 1 & 83 & 1,08 & 14,5 & 89 & 104 \\
\hline & 2 & 36 & 1,11 & 14,5 & 40 & 47 \\
\hline & 3 & 115 & 1,00 & 0,0 & 115 & 115 \\
\hline & 4 & 10 & 1,08 & 10,5 & 11 & 12 \\
\hline & 5 & 62 & 1,06 & 13,0 & 66 & 76 \\
\hline
\end{tabular}

\subsection{Estimasi Hasil Lateks Tanaman Karet}

Estimasi hasil lateks tanaman karet diketahui melalui pertimbangan data historis hasil kebun berdasarkan umur tanaman, klon tanaman, cara pemeliharaan, pemupukan terdahulu, manajemen penyadapan, jumlah tanaman menghasilkan, tanaman belum menghasilkan, dan tanaman tidak menghasilkan, serta luas lahan. Hasil estimasi lateks akan dibagi antara lateks cair dengan kompo dengan komposisi $70 \%$ lateks cair dan 30\% kompo/cup lump. Hasil estimasi lateks tiap kebun kemudian dirapatkan untuk pembagian wilayah pengolahan dan disesuaikan kembali dengan kapasitas terpasang pabrik, untung rugi produksi, dan kebutuhan pabrik. Penyesuaian yang telah dibuat melalui rapat disebut RKAP (Rencana Kerja Anggaran Produksi) yang akan diusahakan oleh pihak kebun dan pihak pabrik dengan berbagai upaya agar hasil lateks tanaman karet sesuai dengan RKAP yang telah dibuat. Hasil RKAP untuk produksi lateks di perusahaan tempat penelitian pada periode tahun 2018 dapat dilihat pada Tabel 3 berikut.

Tabel 3. RKAP Lateks Tahun 2018

\begin{tabular}{cc}
\hline \multicolumn{2}{c}{ RKAP } \\
\hline Jan & 606.026 \\
Feb & 541.565 \\
Mar & 552.420 \\
Apr & 540.850 \\
\hline
\end{tabular}


Tabel 3. RKAP Lateks Tahun 2018 (Lanjutan)

\begin{tabular}{cc}
\hline \multicolumn{1}{c}{ RKAP } \\
\hline Mei & 455.650 \\
Jun & 443.950 \\
Jul & 394.550 \\
Agu & 332.800 \\
Sep & 357.500 \\
Okt & 363.900 \\
Nov & 492.700 \\
Des & 518.050 \\
\hline
\end{tabular}

\subsection{Perhitungan Kebutuhan Kapasitas}

Berdasarkan data RKAP untuk produksi satu tahun kedepan, maka selanjutnya dilakukan perhitungan untuk mengetahui berapa kapasitas tiap stasiun yang dibutuhkan untuk memproduksi produk lateks. Data kebutuhan kapasitas (capacity requirement) dapat dilihat pada Tabel 4 di bawah ini.

Tabel 4. Rekapitulasi Capacity Requirement (CR) Setiap Work Center

\begin{tabular}{ccrrrrrc}
\hline \multirow{2}{*}{ Periode } & \multicolumn{7}{c}{ Capacity Requirement (CR) } \\
\cline { 2 - 8 } & WC 1 & WC 2 & WC 3 & WC 4 & WC 5 & WC 6 & WC 7 \\
\hline Jan-18 & $417.859,3$ & $17.599 .397,9$ & $1.327 .184,2$ & $35.823 .153,7$ & $500.042 .218,0$ & $15.471 .453,0$ & $2.189 .979,3$ \\
Feb-18 & $407.129,6$ & $17.147 .487,6$ & $1.293 .105,3$ & $34.903 .300,9$ & $487.076 .571,4$ & $15.074 .183,2$ & $2.133 .745,9$ \\
Mar-18 & $361.826,8$ & $15.239 .421,6$ & $1.149 .216,5$ & $31.019 .478,3$ & $432.989 .481,2$ & $13.396 .821,6$ & $1.896 .315,9$ \\
Apr-18 & $305.198,2$ & $12.854 .339,1$ & $969.355,6$ & $26.164 .700,0$ & $365.223 .417,4$ & $11.300 .119,7$ & $1.599 .528,4$ \\
Mei-18 & $327.849,6$ & $13.808 .372,1$ & $1.041 .300,0$ & $28.106 .611,3$ & $392.329 .843,0$ & $12.138 .800,5$ & $1.749 .003,6$ \\
Jun-18 & $333.718,8$ & $14.055 .571,0$ & $1.059 .941,5$ & $28.609 .778,6$ & $399.353 .370,2$ & $12.356 .110,5$ & $1.749 .003,6$ \\
Jul-18 & $451.836,4$ & $19.030 .447,4$ & $1.435 .100,7$ & $38.736 .020,7$ & $540.701 .856,3$ & $16.729 .474,1$ & $2.368 .051,8$ \\
Aug-18 & $475.083,9$ & $20.009 .586,5$ & $1.508 .938,4$ & $40.729 .034,9$ & $568.521 .608,8$ & $17.590 .225,5$ & $2.489 .890,9$ \\
Sep-18 & $461.969,9$ & $20.310 .860,1$ & $1.467 .286,4$ & $39.604 .770,5$ & $552.828 .415,1$ & $17.104 .673,4$ & $2.421 .161,2$ \\
Okt-18 & $482.237,0$ & $20.310 .860,1$ & $1.556 .485,3$ & $41.342 .270,1$ & $577.081 .532,6$ & $17.855 .072,0$ & $2.527 .379,9$ \\
Nov-18 & $491.774,4$ & $20.712 .558,2$ & $1.561 .950,0$ & $42.159 .917,0$ & $588.494 .764,4$ & $18.208 .200,8$ & $2.577 .365,1$ \\
Des-18 & $473.295,6$ & $19.934 .268,1$ & $1.503 .258,5$ & $40.575 .726,1$ & $566.381 .627,8$ & $17.524 .013,8$ & $2.480 .518,7$ \\
\hline
\end{tabular}

Rekapitulasi Kapasitas yang Tersedia (Capacity Available) pada setiap Work Center untuk 12 periode mendatang dapat dilihat pada Tabel 5 di bawah ini.

Tabel 5. Rekapitulasi Capacity Available (CA) Setiap Work Center

\begin{tabular}{ccrrrrrr}
\hline \multirow{2}{*}{ Periode } & \multicolumn{7}{c}{ Capacity Available (CA) } \\
\cline { 2 - 8 } & WC 1 & \multicolumn{1}{c}{ WC 2 } & WC 3 & \multicolumn{1}{c}{ WC 4 } & \multicolumn{1}{c}{ WC 5 } & WC 6 & WC 7 \\
\hline Jan-18 & $3.179 .606,4$ & $113.275 .169,3$ & $3.044 .304,0$ & $94.395 .974,4$ & $251.662 .464,0$ & $15.108 .486,1$ & $4.019 .608,8$ \\
Feb-18 & $3.398 .889,6$ & $121.087 .249,9$ & $3.254 .256,0$ & $100.906 .041,6$ & $269.018 .496,0$ & $16.150 .450,7$ & $4.296 .823,2$ \\
Mar-18 & $3.289 .248,0$ & $117.181 .209,6$ & $3.149 .280,0$ & $97.651 .008,0$ & $260.340 .480,0$ & $15.629 .468,4$ & $4.158 .216,0$ \\
Apr-18 & $3.069 .964,8$ & $109.369 .129,0$ & $2.939 .328,0$ & $91.140 .940,8$ & $242.984 .448,0$ & $14.587 .503,8$ & $3.881 .001,6$ \\
Mei-18 & $3.289 .248,0$ & $117.181 .209,6$ & $3.149 .280,0$ & $97.651 .008,0$ & $260.340 .480,0$ & $15.629 .468,4$ & $4.158 .216,0$ \\
Jun-18 & $3.069 .964,8$ & $109.369 .129,0$ & $2.939 .328,0$ & $91.140 .940,8$ & $242.984 .448,0$ & $14.587 .503,8$ & $3.881 .001,6$ \\
Jul-18 & $3.398 .889,6$ & $121.087 .249,9$ & $3.254 .256,0$ & $100.906 .041,6$ & $269.018 .496,0$ & $16.150 .450,7$ & $4.296 .823,2$ \\
Aug-18 & $3.179 .606,4$ & $113.275 .169,3$ & $3.044 .304,0$ & $94.395 .974,4$ & $251.662 .464,0$ & $15.108 .486,1$ & $4.019 .608,8$ \\
Sep-18 & $3.289 .248,0$ & $117.181 .209,6$ & $3.149 .280,0$ & $97.651 .008,0$ & $260.340 .480,0$ & $15.629 .468,4$ & $4.158 .216,0$ \\
Okt-18 & $2.960 .323,2$ & $105.463 .088,6$ & $2.834 .352,0$ & $87.885 .907,2$ & $234.306 .432,0$ & $14.066 .521,6$ & $3.742 .394,4$ \\
Nov-18 & $3.398 .889,6$ & $121.087 .249,9$ & $3.254 .256,0$ & $100.906 .041,6$ & $269.018 .496,0$ & $16.150 .450,7$ & $4.296 .823,2$ \\
Des-18 & $3.289 .248,0$ & $117.181 .209,6$ & $3.149 .280,0$ & $97.651 .008,0$ & $260.340 .480,0$ & $15.629 .468,4$ & $4.158 .216,0$ \\
\hline
\end{tabular}




\subsection{Klasifikasi Bottleneck - Non Bottleneck}

Kecukupan kapasitas produksi diketahui dengan membandingkan antara Kapasitas yang tersedia (Capacity Available) dengan Kapasitas yang dibutuhkan (Capacity Requirement) yaitu melalui perhitungan varians.Varians yang bernilai positif menunjukkan bahwa kapasitas yang diperlukan lebih besar daripada yang tersedia atau kapasitas tersedia belum memenuhi kebutuhan sehingga terjadi botlleneck. Rekapitulasi klasifikasi Bottleneck nonbottleneck untuk penilaian Work Center yang mengalami Bottleneck dapat dilihat pada Tabel 6 berikut.

Tabel 6. Klasifikasi Bottleneck-Non Bottleneck Setiap Work Center

\begin{tabular}{cccccccc}
\hline \multirow{2}{*}{ Periode } & \multicolumn{7}{c}{ Klasifikasi Non Bottleneck (NB) - Bottleneck (B) } \\
\cline { 2 - 7 } & WC 1 & WC 2 & WC 3 & WC 4 & WC 5 & WC 6 & WC 7 \\
\hline Jan-18 & NB & NB & NB & NB & B & B & NB \\
Feb-18 & NB & NB & NB & NB & B & NB & NB \\
Mar-18 & NB & NB & NB & NB & B & NB & NB \\
Apr-18 & NB & NB & NB & NB & B & NB & NB \\
Mei-18 & NB & NB & NB & NB & B & NB & NB \\
Jun-18 & NB & NB & NB & NB & B & NB & NB \\
Jul-18 & NB & NB & NB & NB & B & B & NB \\
Aug-18 & NB & NB & NB & NB & B & B & NB \\
Sep-18 & NB & NB & NB & NB & B & B & NB \\
Okt-18 & NB & NB & NB & NB & B & B & NB \\
Nov-18 & NB & NB & NB & NB & B & B & NB \\
Des-18 & NB & NB & NB & NB & B & B & NB \\
\hline
\end{tabular}

Keterangan: $\mathrm{B}=$ Bottleneck, $\mathrm{NB}=$ Non-Bottleneck

\subsection{Pendekatan TOC untuk Mendefinisikan Solusi Permasalahan}

Pendekatan TOC yang dilakukan untuk mencari solusi permasalahn sebagai berikut.

1. Identifikasi kendala sistem. Stasiun kerja yang mengalami kendala adalah stasiun kerja V dan VI karena mengalami kekurangan kapasitas. Hal ini menyebabkan tidak semua produk dapat diselesaikan, sehingga diperlukan upaya penyeimbangan kapasitas stasiun kerja yang bottlenenck.

2. Eksploitasi kendala. Kendala terjadi karena ketersediaan kapasitas lebih kecil dari kebutuhan sehingga diperlukan upaya penyeimbangan kapasitas. Alternatif solusi yang dapat dilakukan adalah melakukan penyesuaian beban, melakukan lembur, dan perluasan area pengasapan.

3. Subordinasi sumber daya. Profil Beban Stasiun V dan VI memperlihatkan bahwa penyesuaian beban jumlah produksi tidak dapat dilakukan. Hal tersebut dikarenakan setiap periode di stasiun tersebut mengalami kelebihan beban. Optimasi stasiun kerja bottleneck dilakukan dengan solusi over time yaitu dengan menambah jam kerja.

4. Mengulangi proses. Solusi overtime tidak dapat dilakukan untuk stasiun kerja pengasapan sehingga dicari solusi lain yaitu penambahan kapasitas kamar asap. Perluasan kamar asap diperlukan karena peningkatan jumlah produksi lateks menyebabkan semakin banyak sheet yang dihasilkan dari pengolahan basah dan siap untuk dilakukan pengasapan. Sheet memerlukan pengasapan di kamar asap selama minimal 5 hari. Hal ini menyebabkan penumpukan sheet yang terjadi tiap harinya. Perluasan kamar asap diperlukan karena kondisi sheet yang menumpuk hingga keluar dari kamar asap. Selain itu, perbaikan kamar asap Malaka perlu dilakukan, dikarenakan saat ini perusahaan memiliki 44 kamar asap malaka yang tidak dapat digunakan dan membutuhkan perbaikan. Seiring dengan peningkatan kebutuhan lateks, maka dinilai perlu dilakukan perbaikan terhadap kamar asap malaka tersebut untuk meningkatkan kapasitas produksi.

\section{Kesimpulan dan Saran}

Beberapa kesimpulan yang diperoleh setelah melakukan penelitian ini adalah: 
1. Nilai waktu standar yang diperoleh dari setiap elemen kerja bervariasi dengan waktu standar tertinggi 86.400 detik hingga terendah 12 detik.

2. Jadwal induk produksi disusun berdasarkan RKAP yang dibuat berdasarkan pertimbangan hasil lateks tanaman pada setiap periode dengan RKAP terbesar yaitu pada periode September 2018 sebesar $606.026 \mathrm{~kg}$ dan RKAP terkecil pada periode April 2018 sebesar $332.800 \mathrm{~kg}$.

3. Rough Cut Capacity Planning (RCCP) menghitung kapasitas yang dibutuhkan (CR) dan kapasitas tersedia (CA) dari masing-masing stasiun kerja pada periode januari sampai desember 2018. Hasil perbandingan CR dan CA pada perhitungan RCCP diperoleh bahwa stasiun kerja yang mengalami bottleneck yaitu sortasi dan pengasapan.

4. Pengoptimalan stasiun kerja bottleneck dengan menggunakan metode Theory of Constraint merekomendasikan penambahan jam kerja untuk mengoptimasi stasiun kerja V dan VI yang mengalami bottleneck. Selain itu, perluasan dan perbaikan terhadap kamar asap perlu dilakukan untuk meningkatkan kapasitas produksi perusahaan.

\section{Ucapan Terimakasih}

Penulis berterimakasih kepada Departemen Teknik Industri Universitas Sumatera Utara sebagai institusi yang menaungi Penulis dalam melakukan penelitian.

\section{Referensi}

[1] Denisa, Ferencikova, 2012, Bottleneck Management in Discrete Batch Production, Zlin : Tomas Bata University.

[2] Cox, James F and Scheleier, John G Jr. 2004, Theory of Constraints Handbook, The McGraw-Hill Companies, Inc, United States.

[3] Shamuvel, V. Pandit, 2013, Application of Theory of Constraints on Scheduling of Drum Buffer Rope System. KIT'S College of Engineering, Kolhapur.

[4] Caspari, J.A. and Caspari P. 2004. Management Dynamics: Merging Constraints Accounting to Drive Improvement, Wiley, New York, NY

[5] Slack, N. Chambres, S. and Johnston R. 2016. Optimum Production Technology (OPT) and the Theory of Constraints (TOC): Analysis and Genealogy. International Journal of Production Research, Vol 33 No. 6

[6] Wacker, J.G. 2014. A definition of theory: research guidelines for different theory building research methods in operations management. Journal of Operations Mangement, Vol 16 No 4

[7] Kim, S. Mabin, V.J. and Davies J. 2018. The theory of constraints thinking processes: retrospect and prospect, International Journal of Operations and Production Management Vol 28 No 22

[8] Sinulingga, Sukaria. 2015. Metodologi Penelitian. Medan: USU Press 